\title{
FEMALE FIGURES AND CENSORSHIP: THE RECEPTION OF STEFAN ZWEIG IN SPAIN (1946-1960)
}

\author{
INÉS CONDOY FRANCO \\ Universidad de Alcalá \\ inescf95@hotmail.com \\ ORCID: 0000-0002-6801-8747
}

\begin{abstract}
The works of Stefan Zweig have always experienced a very lively reception in Spain from its very first publication in this country in the 1930s. Since the early 2000s his works have been reedited and everything that contains his signature easily finds a readership. This broad reception in Spain has inspired me to explore the nature of the success of Zweig's stories. As the focus of my research paper is set how Zweig reception was possible during Franco's regime in Spain. How it was possible despite the topics and the female image they show, and how publishing houses never stop trying to publish new editions, they knew that readership were demanding it. This descriptive study has been conducted following the evidence that is possible to find in Archivo General de la Administración and studying the comments and reason given by censors in the different reports about in his novellas Amok, Vierundzwanzig Stunden aus dem leben einer Frau and Brief einer Unbekannten in order to find an explanation that can justify the success or failure of Zweig works in Spain during this historical period.
\end{abstract}

KEYWORDS: Zweig, censorship, Spain, reception, literature

\section{INTRODUCTION}

«Never can be the innate power of a work be hidden or locked away. A work of art can be forbidden and rejected but the elemental will always prevail over the ephemeral! » Even though these are the words of Stefan Zweig, he probably never thought that he was describing what would later happen to his own work. Stefan Zweig was born in Austria, a country he would later have to flee due to well-known political reasons, namely the Nazi dictatorship. This paper deals with the success of Stefan Zweig both during his lifetime and after his death. During the 1930s and the 1940s he was one of the most remarkable writers of the period and the most recognized author of the first half of the $20^{\text {th }}$ Century, after Thomas Mann. ${ }^{1}$ Nevertheless, not everything was success around him; he was one among the large number of artists and intellectuals that had to go into exile during the first half of $20^{\text {th }}$ Century, and in his case it was not just because of his political ideology but also due to his Jewish origin.

\footnotetext{
${ }^{1}$ Medina, Marta. "¿Quién Fue Realmente Stefan Zweig? ¿Un Cobarde O Un Pacifista

Radical?". El Conficencial, 2017
} 
The focus of the paper is to be set on Stefan Zweig's reception in Spain between 1946 and the early decade of the 1960s. During this period Spain was a dictatorship under the rule of General Franco, the country was facing difficult political times and its cultural sphere was governed by censorship. Nevertheless, the reception of Stefan Zweig in Spain was extremely positive. This paper aims to analyze the reception in Spain of three selected works and to examine the possible reasons for them being rejected by the Spanish Ministry of Information and Tourism. In order to do so the paper will take into consideration the reports issued by the officers of said Ministry who worked as censors. It is our contention that the representation of women in Zweig's work is of paramount importance in the reception of Zweig's short prose in Spain. Thus, this analysis will pivot around the female characters in Zweig's novellas Amok, Vierundzwanzig Stunden aus dem Leben einer Frau and Brief einer Unbekanten.

This analysis will be descriptive and will attempt to analyze the reasons why censorship was applied on these works through the documents created when publishing houses did require the publication of their editions. In order to conduct the necessary research, both editing houses and archives will be contacted, more precisely: the Spanish National Library, the University of Alcalá, as well as the $A G A .^{2}$

I also want to express my gratitude to professor Ingrid Cáceres, from the University of Alcalá, who will be quoted several times in this paper and who has allowed me to access her yet-to-be published research about Zweig's reception in a previous period. To her and to her colleagues professor Georg Pichler and professor Lorena Silos I am thankful for their support along the process of writing this paper.

\section{STEFAN ZWEIG: CENSORSHIP}

\section{AMOK : THE IMMORALITY OF ABORTION}

This novella was object of a broad number of reports ${ }^{3}$ which dealt with the many immoral aspects of the plot. Amok is, in my opinion, the most «immoral»-always in the context of Franco's regime - of the three examined texts, and, thus, the one that appears to be most problematic for the publishers with regard to censorship. The analysis will look into seven reports in relation to Amok, which were issued between 1946 and 1968 and were created according to the "Orden de marzo de 1944/orden de abril de 1938" with the exception of the last one that was made following the already mentioned law Ley de Prensa e Imprenta de 1968, two of them

\footnotetext{
${ }^{2}$ Archivo General de la Administración, where all the reports mentioned and analyzed were found.

${ }^{3}$ Reports are the register that was created in AGA to register if the addressed work was accepted to be published or not. They are the main source of this analysis.
} 
are common with Vierundzwanzig Stunden aus dem Leben einer Frau. As the analysis will follow a chronological order, these texts will be mentioned twice. Just three of these requested publications were authorized without problems, I have also found four censored editions of Amok. Indeed, the resolution to censor one of them was the origin of a conflict between two different publishing houses. These publishing houses were both Spanish and South American, namely Tor (from Argentina), Plaza y Janés, Juventud and Hispano Americana Ediciones (from Barcelona). These editions were published with a range from fifty to three thousand volumes, according to the information in the reports, which can give an idea how editors trusted Zweig's success among the Spanish readership.

The report of $1946^{4}$ only includes the book with some underlined fragments which will be commented later as examples of the moral problems of this book, but there were no comments about them and no information about the translator either. The second report from $1952^{5}$ also includes a copy of the book, which had been published in 1944 and shows absolutely no evidence whatsoever of the work of the censor. This volume does not just include $A m o k^{6}$ but also other novellas by Zweig, among them, Brief einer Unbekannten, and an introduction to the author. The only comment that we found is an allusion about the previous report of $1946^{7}$ and therefore the request was also rejected. We have two reports from 1952. The first one, from $25^{\text {th }}$ January $1952,{ }^{8}$ is the one about the edition of Obras Completas by Editorial Juventud, in which all the works included were authorized with the exception of Vierundzwanzig Stunden aus dem Leben einer Frau, Amok and Der begrabene Leuchter; in May 1952 Vierundzwanzig Stunden aus dem Leben einer Frau and Amok were disallowed again, but the $7^{\text {th }}$ of May 1954, one year later, were authorized and included in Obras Completas. In the report I have also found two different letters from the publishing house, asking for their request to be reconsidered so that these two works were included in the volume. Despite all these arguments, the letter did not convince the censors; however, there is another communication from 1954 that had more success. It refers mainly to the complaints they had received from the readers that were missing these two novels in the volume. Perhaps the second letter was more persuasive than the previous one, or after two years the institution was somewhat more permissive, or a different censor was in charge of the evaluation. The novel was finally authorized in 1954 and a re-edition was also approved in 1957. In this same

\footnotetext{
4 (21/07826 AGA) Reports are referred with the code they are assigned in AGA.

5 (21/09752 AGA)

${ }^{6}$ All the novellas included in the edition with the titles in Spanish as they appear in the report

21/09752 were : Carta de una desconocida, Amok, Veinticuatro horas en la vida de una mujer, Los ojos del hermano eterno, Momentos estelares de la humanidad, Sendas equívocas, La partida de ajedrez, Una carta, El candelabro enterrado y Tiempo y mundo

7 (21/07826 AGA)

8 (21/09752 AGA)
} 
report $^{9}$ about Amok we can also read the following note, which was probably the reason why the book was not considered to be adequate in a first moment: «La acción de la novela gira alrededor del tema del aborto. Fondo perfectamente inmoral que ni siquiera es compensado por el valor literario. No podemos aconsejar la autorización. ${ }^{10} \gg$ In this comment we can see that the censor was aware of the quality of the book, but still, abortion was a subject completely taboo and it could not be tolerated.

In the report from $1956^{11}$ we find another comment «Amok de Zweig es obra profunda y radicalmente inmoral, basándose la narración en un aborto. Es una obra nociva y gravemente perniciosa.» This comment perfectly illustrates the ideological situation in Spain: if something was not moral, then it should be hidden. Censorship did not only exist in literature, it was present in everyday life and therefore if a book was as immoral as Amok, it was not to be published, since it was showing ideas that the Regime did not like, as the practice of abortion for instance. Obviously, it was rejected and the editor José Janés wrote a letter to the Ministerio de Información y Turismo protesting for the refusal of his request as Juventud had this title published. Some letters from his claim are to be found in the AGA. When he was asked to show an example of the book, Editorial Juventud was punished with a fine.

The resolution of the report 21/11592 cannot be considered as appropriate: when they revised the report 34/52, they skipped or they did not take into account that in the year 1954, as it appears in the last part of the report, this work was tolerated by the organization. There are still two remaining reports: one from $1961,{ }^{12}$ an edition by Tor is the first one I found that was accepted from the very beginning, although the comment is still not positive. The reports from $1962^{13}$ and $1968,^{14}$ on the contrary, are more indulgent. The most remarkable fact is the change of law which has been previously pointed out. This law was less severe and made the acceptance and publication of our studied works easier. The information found about Amok shows that the novel was censored due to the portrait of abortion in the text. It is also remarkable how the book was banned without giving any explanation why, and with the passing of time, reports become more specific and clear, and some even seem to be apologetic for rejecting this piece of literature. The editors also become more insistent even writing letters to try to change the resolutions and 1961 makes the difference, it is the first time when Amok isapproved to be edited.

What follows are some of the fragments in the edition from 1946 which were underlined by the censor (21/07826). They are seen as examples of

\footnotetext{
9 (21/09752 AGA)

10 Comment included in 21/09752 AGA report.

11 (21/11592 AGA)

$12(21 / 13534$ AGA $)$

$13(21 / 14277$ AGA $)$

$14(21 / 18800$ AGA $)$
} 
immorality and support the censor's arguments not to permit the publication of the novella:

Excitaba todo lo que había en mí de pasado, de oculto y de malo para resistirla. Que representando el papel de «lady», reservada y fríamente quería tratar de un negocio de vida o muerte, me volvío loco... y además...además, un embarazo no puede originarse en un partido de «golf»...con tenía que imaginarme, con alarmante claridad, que aquella mujer que orgullosa y reservada, que sobre sus ojos de acero levantaba las cejas al sentirse mirada, tenía que imaginarme, digo, que hacía dos o tres meses se había estrujado con un hombre en la cama, desnuda como un animal, tal vez lanzando gemidos de placer, entrelazados los dos cuerpos como dos labios... Tal era mi ardiente pensamiento, mientras ella me miraba con la glacialidad de un oficial inglés..., y entonces se reveló mi deseo...Tenía el propósito de humillarla... Desde aquel momento empecé a ver a través de su vestido su cuerpo desnudo... Desde aquel memento me ganó la idea de poseerla, de hacer brotar de sus labios un gemido, de sentir la voluptuosidad en aquella mujer fría y altanera, como el desconocido que la había poseído ya. Eso...quería explicarle a usted... Aun hallándome tan caído profesionalmente como me hallaba, jamás pensé en aprovechar determinadas situaciones, prevaliéndome de mi calidad de médico...Pero esta vez no se trataba de lujuria, de ardor, de nada sexual, no, no...Se lo confesaría a usted si hubiese sido así... Sentía únicamente el deseo ávido de dominar aquel orgullo..., dominaren calidad de hombre. Me parece haberle dicho ya, que las mujeres altivas y aparentemente frías me han dominado siempre... Pero a ello se sumaba entonces la circunstancia de haber vivido siete años sin ver mujer blanca, sin haber conocido la resistencia femenidad..., ya que las muchachitas de allí, aquellos animalitos gorjeantes, que tiemblan de respeto cuando las toma un hombre blanco, que siempre se hallan dispuestas a servir, con su modestia y su risa, aquellas muchachitas no cuentan para nada y sólo consiguen hacerle perder a uno el apetito de placer, por sus modales de esclavas... Ahora comprenderá usted que al llegar de pronto una mujer blanca, llena de orgullo y de odio, reservada hasta las uñas, reluciente de secretos y cargada de anteriores pasiones... Al penetrar una mujer así, con arrogancia, en la jaula de una bestia humana, hambrienta y alejada del mundo... (pp. 138-140)

-ya no creo en Dios..., ni en el cielo, ni en el Infierno..., y si existe el Infierno no lo temo (p.155)

Ser médico y no saber nada, nada, nada...; no poder hacer sino permanecer sentado y balbucear una oración cualquiera, como una vieja en la iglesia, y en seguida cerrar otra vez el puño contra un Dios miserable, que no existe?... ¿Lo comprende usted? ¿Lo comprende? Yo... lo único que comprendo es cómo no morí también en aquellos segundos; (p. 161)

En momentos- y entonces apretaba los dientes- iba a brotar de mis labios la verdad; pero jamás pudo saber que ella tenía un hijo de él...; que yo me había impuesto el deber de matar aquel hijo, a su hijo, y que ella lo había llevado consigo a la muerte. (p. 171)

These underlined fragments, which were censored in the report from 1946, show why this text was not considered suitable for the readership: the novella does not only deal with abortion, but it explicitly refers to sex drive and sexual relations, with the act of penetration being mentioned or the main character imagining the sexual act of the pregnant woman. Moreover, all these sexual allusions are around an affair of the female character and, in order to make things worse, the existence of God is being questioned, which was something completely unacceptable for the Regime. Zweig shows in this novella two 
different models of women: a slave, a submissive women with no initiative and the «new Woman», who is making a step into Europe and who is self-assured, autonomous, and most importantly sexually active. This female model did not correspond with the female image supported by the Francoist regime, for which the place of the women was solely at home, as safeguard the domestic values of the national-Catholicism. Regarding the main character, the doctor also acts as «a voyeur», he does not just describe graphically the sexual act, he also seems to be excited to think of the image, so it can be considered as a voyeurism scene, because he does not see the scene in real life but it is on his mind.

\section{VIERUNDZWANZIG STUNDEN AUS DEM LEBEN EINER FRAU: A PASSIONATE AFFAIR}

This paper deals with eight reports (of a total of sixteen) regarding the novella Vierundzwanzig Stunden aun dem Leben einer Frau and the methodology has the same criteria as in the analysis of Amok. All these reports were issued between 1951 and 1982 while the oldest registers in the BNE are from 1933, 1935 and 1938 which is much closer to the original publication date. The analysis will concentrate on reports from 1951 and 1952. The first one was issued after a request from the Argentinian publishing house Tor, which was rejected not only for the mentioned fragments, but also due to the allusions to the communist Russian revolution that appear in the prologue written by Manuel Ripamonti. The second report, issued in 1952, refers to Obras Completas and has been mentioned above. With regard to Vierundzwanzig Stunden aus dem Leben einer Frau, the censor added: «Relato de fondo inmoral que contiene gran cantidad de pasajes reprobables. NO se puede aconsejar la autorización. ${ }^{15} \gg$ In 1956 this novel was rejected again, and the editor tried to convince the institution to reconsider its decision, but the results of his insistence were new comments about the lack of morality of the novel. As it has already been explained, something similar happened with Amok in the report 34-5216 and how the decision in which the work was tolerated in the year 1954 seemed to be forgotten (the description of the whole problem is described in detail in Amok's analysis with the same signature number). In $1961^{17}$ Vierundzwanzig Stunden aus dem Leben einer Frau was allowed to be published, albeit pointing out some inadequacies in the plot in relation to the female character. Even if the female protagonist has an execrable behavior, her terrible fate will dissuade readers to attempt to imitate it:

«Ciertamente esta idea del destino es poco cristiana y fácilmente lleva a excusar conductas de todo punto censurables. De todos modos, la invocación que aquí se hace del destino no supone más que su presencia indirecta y pudiera decirse tácita. $Y$ en cuanto a la conducta de la mujer, un tanto anómala, ciertamente no queda justificada aunque de algún modo se

\footnotetext{
${ }^{15}$ Comment that can be found in the report 21/09752 AGA.

16 (21/09752 AGA)

17 (21/13534 AGA)
} 
hace explicable. No creo que nadie por lo que le ocurre a la señora se sienta tentado a hacer lo mismo; más bien se saca la impresión contraria: la de que hay que verse cogido en malos trances que sin intentarlo le desempeñan a uno.»

The report of $1962^{18}$ also had a positive answer and has already been mentioned in the analysis of Amok. About $1965^{19}$ and $1969^{20}$ report it is necessary to emphasize that in 1965 was considered as a psychological novel. Again we can see that is 1961 the significant date when even if the comment shows us that the institution did not fully agree to the novel theme they consent to its publication. It is also important the 1965's judgement when the work it is not immoral anymore but psychological. The fragments below show the main arguments for the censor to stop the publication of this work in $1951^{21}$ by Tor.

El autor nos muestra, en el brevísimo tiempo de veinticuatro horas, toda la intensidad de la pasión sofrenada durante años. Es el amor fulminante de una mujer ya en el otoño de la vida, por un muchacho desconocido al que encuentra al borde del suicidio. Todo el drama, naturalmente, el extraño idilio, se desarrolla en una sola noche. Vivísima luz penetra en el abismo de aquellas dos almas. La naturaleza humana desnúdase con extraordinaria franqueza y queda palpitante hasta una irónica duda. El hombre -y, en el caso, la mujer - cede por una vez ante las fuerzas misteriosas y omnipotentes del demonio. Rómpense lo prejuicios. Cede la llamada virtud, derrúmbase el convencionalismo y, en plena tempestad de pasión, triunfa la carne e impone su categórico yugo hasta el punto de amenazar con toda una catástrofe moral. P34[...]más fuertes, morales y puras, que las que resultan "fáciles de seducir". Personalmente yo encuentro más digno que una mujer ceda el instinto, en forma libre y apasionadamente, a que, como por lo general ocurre, engañe al esposo en sus propios brazos y a ojos cerrados. (p.16)

Sin aquella horrible casualidad, yo no hubiera sospechado jamás con cuánta avidez, con cuánta desesperante frenesí, el hombre que se siente perdido se empeña todavía en sorber una vez más las rojas gotas de la vida apartada, hacía veinte años, de las demoníacas fuerzas de la existencia de la existencia, nunca habría comprendido en qué forma magnífica y fantástica la naturaleza junta algunas veces en fugaces instantes el calor y el frío. La muerte y la vida, la alegría y el dolor. Aquella noche estuvo tan llena de luchas y de palabras, de pasión y de cólera, de odio y de lágrimas, de promesas y de embriaguez, que me parece que duró mil años. Hundidos en el abismo, dando tumbos, él deseando locamente la muerte, yo absolutamente ajena a lo que había de acontecer, salimos los dos de aquel tumulto mortal transformados, con otros sentimientos y muy distintos sentimientos. (pp. 104-105)

[...]y dejé de sentirme avergonzada, experimentando casi una sensación de júbilo. Súbitamente, lo que ofrecía de horrible y de inconcebible aquella situación mostró para mí un sentido y una razón de ser. Me sentí contenta y orgullosa, pensando en aquel hombre joven, bello, delicado, que sereno y silencioso allí dormía, como una flor, quizá sin mí abnegada intervención, hubiera sido encontrado entre las rocas, con el rostro partido, bañado en sangre, destrozado, sin vida y con los ojos espantosamente abiertos. Yo lo había

\footnotetext{
18 (21/14277 AGA)

19 (21/16788 AGA)

20 (03428 AGA)

${ }^{21}$ (21/09612 AGA) The fragments correspond to the edition of the book that was part of the report from 1951 published by Tor.
} 
salvado. Ya ahora-no puedo manifestarlo de otro modo-contemplaba maternalmente a aquel muchacho dormido, a quien de nuevo-- ¡con dolor, como a mis propios hijos! - había dado el ser. (pp. 111-112)

Vierundzwanzig Stunden des Lebens einer Frau not only includes the story of an affair and two illegitimate lovers, but the entire story is surrounded by gambling, the figure of the devil that makes the woman act in this way, which goes against the Christian faith of the Regime. Moreover this old lady considers the possibility of abandoning her family for her lover and once again, the allusions to sex and passion are too explicit. Zweig even describes the hotel room where they stayed. But a question comes to my mind, why is this novel more acceptable than Amok? Perhaps due to the limited span of time in which the action takes place-namely twenty-four hours-and which could justify sins as a consequence of human weakness. Furthermore, the text is slightly pedagogical, since the female character is «punished» with sorrow and affliction throughout the novella, and therefore readers will probably not want to imitate her. Also the language is far less explicit than in Amok.

\section{BRIEF EINER UNBEKANNTEN: SON OF ONE SIDE'S LOVE}

The analysis of the reports regarding Brief einer Unbekanten will concentrate primarily on the four reports in which the text was rejected and on the one which accepted the novel after a revision. The report from 1952 regarding Obras Completas will be examined once again, since Brief einer Unbekanntem was also included in this edition, although it did not represent a problem for the censor. There are two reports in which we have found strike out fragments, one from $1946^{22}$ and the one from $1949,{ }^{23}$ and the one to be analyzed will be the one from 1946. Regarding the number of books in each edition we have found between 300 and 1200 books.

The first report from 1946 in the response to a proposal by Hispanoamericana Ediciones that was rejected with no comment to justify this decision. Instead, we can find some marked sentences and fragments, those are the ones that will serve as an example of the immorality in the novel and that will be shortly commented as well. In a report from year $1949,{ }^{24}$ the novel was first censored and later tolerated even if it was described as a «voluptuous novel», ${ }^{25}$ Perhaps a request from the publishing house might have fueled the change of opinion among the censors or else a different person was in charge of the publication of this specific text. The report from $1956^{26}$ includes several comments in which the novel is not really well considered. It was an edition

\footnotetext{
$22(21 / 07826$ AGA $)$

$23(21 / 08603$ AGA $)$

${ }^{24}(21 / 08603$ AGA)

${ }^{25}$ (21/08603 AGA) Comment of the censor originally in Spanish "novela voluptuosa"

${ }^{26}(21 / 11394$ AGA)
} 
together with Sendas Equívocas. Brief einer Unbekannter was the only story of our three studied ones that was authorized to be published. Later in $1963^{27}$ and $1978^{28}$ the novel was published without almost any inconvenience. The fragments below correspond to the ones that where strike out on the 1946 edition, they were the argumentation of the immorality of the work: ${ }^{29}$

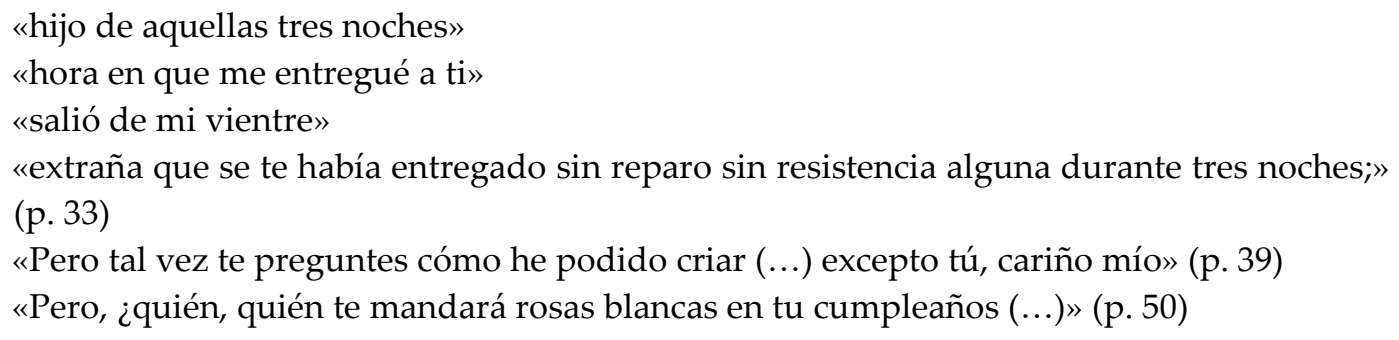

The underlined fragments show the censor's opinion on the text. Although the text is not as explicit as Amok, the topic is still immoral for the censor. Still, the story focus onan illegitimate son and once again, this woman and her son suffer a lot and it can be understood as a moral. The fact that the main character offers him white roses, when white is the colour associated to purity and neither the actions nor the relationship they kept could be considered to be pure, should also be remarked.

\section{CONCLUSIONS}

Despite the success that Zweig's work has always had in Spain, his reception has gone through different stages. We can revise the Spanish $20^{\text {th }}$ century history through the changes on its reception, mainly in what refers to the influence of the Ministerio de Información y Gobierno. From the editions we have worked with, it seems that most books by Zweig were easily published in Spain during the Second Republic. It is not that censorship did not exist during that period, but it seems that Zweig's literature fit in with their criteria. Everything changed with the arrival of the Regime and its moral values - «fe, familia y patria» - in which Zweig's immoral characters that questioned the faith, broke their families and moreover were women, could not be accepted. Even though censorship gradually relaxed their criteria, becoming more tolerant with Zweig's literary production. 1961 represents a turning point: Zweig is not rejected anymore and

\footnotetext{
$27(21 / 14380$ AGA)

28 (73/06453 AGA)

29 These fragments are included in the exemplar of the book found in the report 21/07826. It does not really correspond with any published edition, it seems a kind of notebook of 80 pages and includes the title and the name of the author, the word "novela" in Spanish and a stamp from the publishing house in the front page. They also clarify with a separate note that is the only exemplar they had, and it is included as one of the documents of this report.
} 
to be tolerated under a punishing comment, it happened in the three works therefore I would mark it as a change of trend. Even if the Regime's censorship didn't make it easier for the readers to access Zweig, his literature has never stopped being read and it makes me wonder, why? After all this research I would say that female characters are the reason for the enormous interest Zweig has always awakened among the Spanish readership. These feeble, fickle women were attractive because they represented exactly those obscure secrets and sins society had to hide at that time.

\section{BIBLIOGRAFY}

Acosta Gómez, L.A (1989), El lector y la obra. Teoría de la Recepción. Madrid.

Boyero, C. (2017), Descanse En Paz, Admirable Zweig, El País.es

BuRGOS, E. (2017), Richard Strauss Y Stefan Zweig En Viena, Heraldo.es

CÁCERES, I. (awaiting publication) La recepción en España de la obra de Stefan Zweig durante la Segunda Guerra Mundial.

CÁCERES, I. (2017), Stefan Zweig y Alfredo Cahn la influencia de la Primera Guerra Mundial en el binomio autor traductor, V\&R Unipress, Franfurkt, 127-135.

Available at:

https://www.researchgate.net/publication/311983727_Stefan_Zweig_y_Alfredo_Cahn_la _influencia_de_la_Primera_Guerra_Mundial_en_el_binomio_autor-traductor [Accessed 23 February 2017].

DE BLAS, J.A., (1999), El libro y la censura durante el franquismo: un estado de la cuestión y otras consideraciones, Espacio Tiempo y Forma. Serie V, Historia Contemporánea, 281-301.

FORSTER, E. M. (2001), Personajes planos y personajes redondos. Teoría de la novela. Antología de textos del siglo XX.

GIMÉNEZ BuRGOS, E. (2014), Richard Strauss y Stefan Zweig en Viena, Heraldo.es IRIARTE LÓPEZ, M., (2004), El retrato literario, Pamplona.

ISABEL, H. (2013), ¿Un amor imposible? Acerca de la traducción de literatura alemana en España durante el siglo XXI, Estudios de traducción, III , 315-327.

LEIVA, J. (2003), Recepción literaria y traducción: estado de la cuestión, TRANS, Revista de Traductología, VII, 59-70 .

MAYORAL, M. (1990), El personaje novelesco, Cátedra, Madrid

MediNA, M. (2017), ¿Quién Fue Realmente Stefan Zweig? ¿Un Cobarde O Un Pacifista Radical?, El Conficencial.es

MEREGALLI, F. (1985), Más sobre la recepción literaria, Anales de literatura española, IV, Alicante. 271-285

PAPEL EN BLANCO (2015), Sendas equívocas, tres relatos cortos de Stefan Zweig, Papel en blanco.

PICHLER, G. (2013), Stefan Zweig in Spanien, Salzburg.

PRIVATE CORRESPONDENCE with Acantilado publishing house.

ROHTER, L. (2014), Stefan Zweig, austrian novelist, rises again, NY Times.com

Romero, S. (2011), Stefan Zweig, Viennese-Born Writer, Gets Fresh Look In

Brazil, NY Times.com 
ScotT, A. (2017), George Prochnik'S ‘Impossible Exile,' About Stefan Zweig, NYTimes.com

SENABRE, R. (1997), El retrato literario,

SERVÉN DÍAZ, C. (2007), La mujer en los textos literarios, Madrid.

Soní Soto, A. (2009), Teoría De La Recepción. Fundamentos Teóricos Y Metodológicos. Hermenéutica y literatura, Aracelisoni.blogspot.com

VALLENAJERILLA.COM (2017), La mujer durante el franquismo, Biblioteca Gonzalo de Berceo, Burgos.

WALTON, S. (2017), Stefan Zweig? Just A Pedestrian Stylist, The Guardian.com

WOLFGANG, I. (1987), El acto de leer: Teoría del efecto estético. Madrid

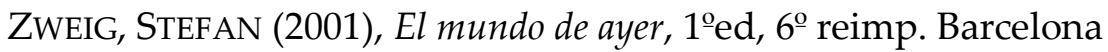

ZWEIG, STEFAN; MARÍA DANIELA LANDA (2015), Veinticuatro Horas En La Vida De Una Mujer, Barcelona.

ZWEIG, STEFAN (2003), Carta de una Desconocida, Madrid.

ZWEIG, STEFAN (2016), La Censura En La II República, ABC.es

ZWEIG, STEFAN (2012) Stefan Zweig Se Suicidó En 1942 Tras Ver A Europa Destruirse A Sí Misma. Elpaís.es

ZWEIG, STEFAN (2017), Why europeans are reading Stefan Zweig again, Economist.com 